\title{
METHODOLOGICAL PROBLEMS IN THE STUDY OF THE PSYCHOLOGICAL ASPECTS OF SOCIAL CHANGE
}

\author{
G.M. ANDREEVA ${ }^{\mathrm{a}}$, A.N. LEONTIEV ${ }^{\mathrm{a}}$
}

${ }^{a}$ Worked at Lomonosov Moscow State University

\begin{abstract}
The paper introduces the concept of social change in the context of social psychology. There are three levels of social change. (1). Radical transformations of the type of social relations and the economic formation through social revolutions. (2) System-level changes of specific domains of social practice such as education, mass communication, etc.. (3) Changes affecting vital activities of small groups or separate individuals. The psychological aspect of social change (especially of the two upper levels), is limited by the study of the individuals' perception of these changes, which sets the limits of competence for psychology in studying macro changes. However, the third level of social change makes the field of both social and, incidentally, general psychology. The specifics of the psychological study of social change at different levels is associated with different layers of methodology ranging from a general philosophical basis to special methods of research; the contribution of different layers of methodology varies across the levels of social change. The issue of resistance to change also requires different treatment depending on the level of analysis. Also discussed are the possibilities and limitations of an experimental research strategy. Lack of recognition of a broader social context is stated as a weakness of contemporary social psychology that needs to be corrected. Focusing on changes would bring social psychology closer to life problems, because the human situation in general is always a social and a changing one. Facing the challenge of change, an individual is involved with an inner conversation or an inner struggle to adapt to the change while maintaining personal self-esteem.
\end{abstract}

Keywords: social change, levels of methodology, resistance to change, experimental strategy, social context, human situation.

As an independent field of study, the concept of social change has no place, strictly speaking, in the subject matter of social psychology. In the existing division of sciences, social change is primarily a problem of sociology. Therefore, before elucidating the specific interest of the psychologist in the investigation of this problem, we should 'apply' the answers that sociology gives to it.

Here too, as is well known, not all researchers employ the concept of social change with the same meaning. First of all, there is a difference in the principle between the approaches to the essence of social change within the Marxist and non-Marxist conceptions of sociological knowledge. But there is also non unanimity among researchers who generally accept the treatment of the problem that is traditional in the West, as well as in their evaluation of various degrees of social 
change. In social psychology it is impossible to study it, unless we define what we have in mind when we use this fairly broad and undefined concept.

As a minimum we can, it would seem, distinguish three quite different levels of social change possible in society and, accordingly, three possible scales of investigating them.

The first level is linked with the broadest interpretation of social change, when we have in mind the radical transformations of the type of social relations expressed in social revolutions in transitions from one socio-economic formation to another, and so on. It is here that the Marxist sociological tradition considers another conceptual apparatus to be much more pertinent, one that discloses the social content and political form of the transformations taking place. Moreover, great attention is paid here to the problem of the trend or tendency of this change, and the concept of social progress is employed.

The second level is the changes that occur within the confines of a single type of society and concern separate aspects of the social organism: economies, cultures, techniques, or even narrower spheres, such as systems of education, systems of mass communication, and so on. For this level it would be necessary to introduce major amendments to the term "social change" since even in connection with these specific fields of change, it is too general and formal, because it does not pin down the connection between social change and the main features of the socio-economic system in the conditions of which the change is taking place.

Finally, the third level is the whole field of changes that refer to the vital activity of any social group, including small groups and also separate individuals. In this case the category "social change" essentially embraces the individual changes widely studied in social psychology, for example attitude change, changes in cognitive structures of the personality, and so on.

In this connection we would like to comment on Prof. Taifel's statement that social change should be understood as a certain fundamental characteristic of the social environment, that is to say not simply transformations of the technological, social and political structures but also the "ontogenetic phenomenon", i.e. the definite movement of the individual's activities and reactions during his or her whole life in connection with alterations in the environment (Israel \& Tajfel, 1972). There is no doubt that the set of questions described by that is not only important in it itself but is also significant for analysis in social psychology. But it is difficult to include it also under the term of social change.

The classification of social change proposed above, though fairly approximate, is quite necessary to our view before we can begin to define the 'limits' of the psychological approach to studying the problem. The three levels of social change described enable us now to formulate the positions from which their study by the social psychologist will be justified. However vague and undefined the term "social change" may be, the circle of the phenomena of objective social reality embraced by it is very significant in social psychology. Two aspects may be distinguished, which are particularly important for investigating the determination of social behaviour.

First, any social change considered at the first two levels, naturally also includes corresponding changes in the psychology of large social groups, in particular of 
classes, and in the consciousness of separate individuals. The subject of the analysis in this case may be both the perception of the objective changes by an individual or a group and the change itself as an activity of individuals or groups under the effect of these objective changes. There is a great variety of different trends of research here: the spheres of production, culture, education, the family, and so on.

On the other hand, every objective change in the life of society involves changes as a consequence in one or another of the forms of human communication and interaction traditionally studied by social psychology. Inter-group relationships are altered in accordance with the general character of the social relations; for Marxism relations between classes and between nations are particularly important here (in the second case it is interesting to trace how people's concepts of one another, and in particular ethnic stereotypes, are 'set' by the relations that arise between ethnic groups in new conditions of social development). It is also easy to show that such processes as urbanization, for example, also considerably modify forms of communication; the processes of communication in turn are largely determined by technical innovations and the structure of means of mass information.

These two aspects of the connection between social changes and changes in people's consciousness would seem to be what we may define as 'the psychological aspect of social change'. In this key social psychology turns to study social change at the macro-level as it can hardly pretend to do more. The very structure of social change, the pauses bringing it about, and its objective social consequences are a subject for sociological analysis, and no 'psychologizing' of this objective aspect of social change can be considered a suitable methodological position. Our thesis on this point is that psychological reductionism is also becoming discredited in the analysis of social change as in the analysis of other social relationships. The 'prestige' of social psychology is not diminished by the limiting its sphere of interest. On the contrary, the methodological principles of its approach become the more significant, the more clearly and relevantly the object of investigation is lineated.

There is also the third 'block' of social change within the social psychology, framework, though applying the term 'social change' to it is disputable. This is a broad circle of phenomena, including changes in individual and group positions, views, convictions, attitudes to very local objects, other people, and features of the environment, etc. Without clinging to the term, it can be agreed that this 'block' is a real field of social psychology, and also, incidentally, of general psychology. In practice it may take in any psychological research, since psychology deals with changes in the psyche. Problems of changes in cognitive behaviour have proved more rewarding in social psychology, and the sphere of changes of attitude has even acquired the status of an independent field of research. In all theories of balance the process of change in cognitive structures figures as a direct regulator of social behaviour, be it Heider's p-o-x model, Newcomb's theory of communication, or Festinger's theory of cognitive dissonance. In the last, the conceptual apparatus is worked out in detail, for example for analysing the form of resistance to change arising during the reduction of cognitive dissonance. One may, of course, give an interpretation to the whole aggregate of the processes of socialization in terms of 'change'. And as we know, it has been suggested in recent years, especially in con- 
nection with the publication of Toffler's Future-Shock, that the whole problem of adaptation should interpret the term of change; the outlook for the mental health of a person is defined in accordance with the limits of the changes to which he or she can adapt themselves (Toffler, 1970).

Even if we take the apparatus of concepts of "change" in this field as a general conceptual framework, its usefulness as such has still not, in our view, been demonstrated - many new conceptual amendments and qualifications are required so that research can be completed and not limited to the artificially created confines of a rigid conception embracing heterogeneous phenomena under the single term "social change".

The general scheme proposed here for the psychological approach to studying the problems of "social change" has a direct connection with developing methodological principles of the analysis. Some of these principles are quite common, but nevertheless need to be recalled. First, it is necessary to agree on what we mean by "methodology". The interpretation of this term (quite common for a long time in the West as a synonym for methods and procedures) has now become obsolete to a considerable extent. "Methodology" is coming more and more to embrace not only the methods and techniques of research but also a wider round of logical and methodical principles of the structure and organization of knowledge; and with it there is a noticeable tendency to interpret these principles not as purely formal norms of the structure of knowledge but to include analysis and the substance of analysis, for which it is necessary to pose a number of epistemological problems. As regards the Marxist tradition of investigating the process of cognition, it is convenient here to distinguish three levels of methodology: (1) the general methodology of scientific knowledge represented by a definite philosophical method, in Marxism in particular the method of dialectical materialism; (2) the special (or individual) methodology of each separate sphere of knowledge (e.g. the methodology of psychology, or social psychology, and so on), represented by the concretization of the general philosophical method as applied to a given field of knowledge (or a discipline).

At this second level the principles for analyzing the given subject-matter of the field are formulated, being developed on the basis of the more global, more general principles contained in the philosophical method adopted. For example, the special methodological principles adopted by the Soviet school of psychology is the principle of activity, or the principle of the historically conditioned psyche. This means that the basic content of the epistemological problem, for example, the standpoint of analysis of its socio-historical determinant, given is that the personality is interpreted at once as the object and as the subject of social relations. A hypothesis in social psychology is consequently formulated on the condition that a certain definite Image of Man and Image of Society, and some definite type of relationship between them, are adopted. The logical norms for formulating a theory or for designing an experiment, and the means of verifying a hypothesis are drawn up on a definite model (as regards content) of some phenomena or other in social psychology. 
(3) The third level of methodology is its traditional understanding as an assemblage of methods, techniques, and procedures of research. The elaboration of concrete scales for measuring attitudes, to take the example of a component of methodology at this level, also cannot be discussed in isolation from the more general principles accepted in research. It is at this higher "stage" of methodology that the technical methods of research are linked with the initial theoretical promises.

If we now pass on to formulating methodological principles acceptable in social psychology for analyzing the psychological aspects of social changes, we should first conclude that the various types of task arising in these studies call for the inclusion of a different combination of mythological principles in each specific case. The general philosophical approach of the researcher remains the same, unless his or her position is eclectic. But, social psychologist's concrete methodological equipment must differ whether he or she proposes to analyze the psychological aspect of mass social movements or, for example, changes in the concept of the 'Other' during the socialization of a child.

Transfer of the concepts that we employ to describe individual changes (or, to use Toffler's term, "vital changes") in attitudes, cognitive structures, etc., to the field of macro-social changes is not, in our view, methodologically admissible. "Resistance to change" in the theory of cognitive dissonance is clearly not identical with "resistance to changes", if by that we understand the psychological position (attitude) of some social group or other to changes taking place in the economic field or in the system of education in society as a whole. The complex of causes behind "resistance to change" can only be analyzed in any way fully provided that the content and level of the changes are properly described. In the opposite case we are again easily brought back to psychological reductionism, and begin to explain a change in the psychology of social groups through the prism and in the terms of change in the attitude or position of the individual. The complex of causes lying behind the development of the "resistance to change" in itself includes factors of a different degree of generality, depth, and significance. The special methodology of research in social psychology must be quite flexible in the sense of opportunities for applying it at various levels of analysis.

The special problem (and generally in research in social psychology) is one of the possibility of an experimental strategy in studying the psychological aspect of social changes. There has been no lack of discussion in recent years on the theme of the fate of the experiment in social psychology. The 'sterility', especially of laboratory experiments, is not simply associated with the 'vacuum', in which they are carried out, but also (as Prof. Tajfel has shown) is linked with their inability to predict social behaviour in conditions of change. This 'charge' is so vital that we must discuss the question in more detail.

The problem of how far the strategy of research in social psychology can be an experimental one means the following on the plane of the problem of 'social change': can the whole complex of problems relating to the 'psychological aspect of social change' only be grasped by means of experimental method? If we agree with the definition of its content proposed in the present paper, the answer can only be negative. As a matter of fact, the perception of macro-social changes in large social 
groups, and the changes in their psychology under the impact of these changes, cannot be adequately described solely by experimental methods. Furthermore, the laboratory experiment is practically excluded for all general purposes in a number of cases when we are concerned with big social groups.

But in that case is a strategy of experimental research justified in analyzing changes affecting attitudes, individual views, and the cognitive structures of the individual? There is a tendency in criticism of the limited character of experiment in social psychology, we know, to throw doubt on the possibility of forecasting social behaviour in an experiment, since no extrapolation of the conclusions to objective reality can take the factor of the changes into account taking place in that reality (and that will take place in it). Thus a most important determinant of social behaviour is excluded in principle. This objection is vital; but, in our view, is more significant in itself than in regard to the problem of social changes. Let us explain our idea.

In general it should not be claimed that laboratory experiments that record change in the individual's attitude can be considered a method of research in social psychology. It is a legitimate method in general psychology, the purpose of which is to study the mechanism itself of a change of position, attitude, views, etc. In evaluating the possibilities of laboratory experiment in research in social psychology, serious logical confusion creeps in; the debatable statement that any individual change can be taken as a social change is presented as indisputable. And then a method suitable for analyzing individual changes is declared inadequate for analyzing real social changes. In fact, what is criticized here is not the method but the false initial theoretical reasoning. It will be quite clear from this example that the blurring of the term 'social change', and the introduction under it of too wide a round of essentially different phenomena, does not help us to develop the methodological principles of research for what may be classed as the 'psychological aspects of social change'.

It is just the same, in our view, with the exaggeration of the idea that the outlook for transforming social psychology into a more mature and developed science is linked simply with its recognition as the main discipline investigating social change. When the vast bulk of work, especially of experimental research in contemporary social psychology, is criticized in particular for its lack of 'socials context', for the philosophical and methodological 'irresponsibility' observed in it, and finally for the avoidance everywhere felt in it of the moral and ideological collisions of our times, one can agree. But it is hardly serious to expect that all these deficiencies will automatically be overcome if only social psychology turned its attention to social changes. The fact that this problem is vital and significant can hardly be disputed. It is just as unlikely that the idea can be rejected that the times and society must dictate (its) (their) problems and tasks to science, and in particular to social psychology, and stimulate it to develop new methods of research, and not the other way round, to force the problem into the framework of already existing methods. Nevertheless, by simply recognizing social change as a most important factor in the life of society in the twentieth century, and by simply drawing attention to it from 
the side of social psychology, we will obviously not have it cured of all its inherent weaknesses.

We must seemingly seek out the still unrealized possibilities of social psychology in the very principles of the organisation of scientific knowledge, We suggest that the high road for its development lies along the line of carrying out in practice the principles of social knowledge developed by Marxism and real mastery of all the gains of psychology.

Having this perspective in mind we deem it important to have the notion 'change' in social psychology and in psychology in general. It is a new life situation in which human beings reveal themselves primarily as personalities. A human situation is always in fact a social and changing one. Therefore, the research of change will really bring social psychology closer to life problems.

There are, of course, still great difficulties to overcome in programming such types of research, in singling out real problems. We do not pretend to raise all these problems, but we would like to draw your attention to some theoretical assumptions which to our mind should be taken into consideration.

I. Although human beings are always the subject of social change, they are nevertheless each time confronted with change that has already emerged. Here the question inevitably arises: in what frame of reference is it possible to adequately describe the reaction of the individual and of the group to this change. Behaviorism describes it in such terms as adaptation conditioning and reinforcement. According to the opposite point of view, which corresponds to the Marxist approach to human activity and consciousness, the individual in a group or the small group as part of a larger social unit should actively work out their new position and the image of their life. It needs considerable inner effort to realize and to evaluate the emergent situation, to revise the formed motives and value orientations. Naturally this process takes place in the mind of each individual, but always in their interaction and communication in a group or a larger social community. Sometimes this process takes a covert form, that of an individual's internal conversation with themselves. But even in this case the individual remains in the context of social relations since it is simply impossible for him or her to get out of them.

This process cannot be properly understood with the help of such notions as adaptation and reinforcement. The term 'struggle' would be more appropriate here meaning not the struggle for a mere physical survival, but the struggle of a human being for his or her self-esteem as personality. The contents of this struggle depend on the nature of a social system, where the struggle goes on, and on the status that the individual or the group have in this system (in a class society - under the conditions of class struggle, in a socialist society - under the conditions of struggle for the people's common interests). If we want to research the psychology of social change, we cannot abstract ourselves from the concrete historical conditions. The program of social psychology should first and foremost take them into consideration.

Of course, objective social conditions alone do not explain all the problems of social psychology. It is important to designate the more concrete mechanisms that are to be researched. Take, for example, the nature of cognitive stereotypes. It is not 
yet clear how such a change is proceeding as the discredit of imaginary values imposed by the interests of a certain social group, and the search for new values. This problem is connected with other problems that are hardly researched (investigated), for instance, that of affective accumulations, which cannot be explained with reference to frustration or aggressiveness inferred from human nature. All these phenomena are brought about by social relations. They are symptoms, and not factors. For instance, conformism is also a symptom that may indicate different social psychological phenomena. And finally we think it is necessary to revise critically the role of the notion when referred to personality or to intragroup relations and especially when applied to the research of change.

We have mentioned only some problems here. Their number and complexity will no doubt increase as soon as we start the actual research. But we have to raise and solve these problems if we really want social psychology to enjoy the status of a mature scientific discipline.

\title{
References
}

Israel, J., \& Tajfel, H. (Eds.). (1972). The context of social psychology: a critical assessment. London: Academic Press.

Toffler, A. (1970). Future-shock. London: Random House.

Andreeva Galina Mikhailovna (1924-2014) - Doctor of Philosophy, Professor, Honored Scientist of the Russian Federation, Full Member of the Russian Academy of Education, the founder and long-term Head of the Department of Social Psychology at Moscow State Lomonosov University (1972-1989).

Leontiev Alexey Nikolaevich (1903-1979) - Doctor of Psychology, Professor, Full Member of the Russian Academy of Education, the founder and permanent dean of the Faculty of Psychology, Moscow State Lomonosov University (1966-1979).

\section{Методические проблемы исследования психологических аспектов социальных изменений}

\author{
Г.М. Андреева ${ }^{\mathrm{a}}$, А.Н. Леонтьев
}

${ }^{a}$ работал(а) в МГУ им. М.В. Ломоносова

\section{Резюме}

В статье представлена концепция социальных изменений в рамках социальной психологии. Существует три уровня социальных изменений: (1) Радикальные преобразования типа социальных отношений и экономической формации посредством 
социальных революций. (2) Происходящие на системном уровне изменения конкретных областей общественной деятельности, таких как образование, массовая коммуникация и т.д. (3) Изменения, влияющие на жизнедеятельность малых групп или отдельных лиц. Психологический аспект социальных изменений (особенно на двух верхних уровнях) ограничен изучением восприятия человеком этих изменений, что сужает рамки компетенции психологии при изучении макроизменений. При этом третий уровень социальных изменений входит в область социальной и, кстати, общей психологии. Специфика психологических исследований социальных изменений на разных уровнях связана с различными уровнями методологии: от общих философских основ до специальных методов исследования. Роль разных уровней методологии варьируется в зависимости от уровня социальных изменений. Вопрос о сопротивлении изменениям также требует особого рассмотрения, определяемого уровнем анализа. Также обсуждаются возможности и ограничения экспериментальной стратегии исследований. Отсутствие признания более широкого социального контекста определяется как слабость современной социальной психологии, которой необходимо уделить внимание. Исследование изменений способно приблизить социальную психологию к жизненным проблемам, поскольку человеческая ситуация в целом всегда является социальной и меняющейся. Перед лицом перемен человек вовлечен во внутренний диалог или во внутреннюю борьбу с целью адаптации к изменениям, сохраняя при этом личную самооценку.

Ключевые слова: социальные изменения, уровни методологии, сопротивление изменениям, экспериментальная стратегия, социальный контекст, человеческая ситуация.

Андреева Галина Михайловна (1924-2014) - доктор философских наук, профессор, заслуженный деятель науки РФ, действительный член РАО, создатель и многолетний заведующий кафедрой социальной психологии МГУ имени М.В. Ломоносова (1972-1989).

Леонтьев Алексей Николаевич (1903-1979) - доктор психологических наук, профессор, действительный член РАО, создатель и бессменный декан факультета психологии МГУ имени М.В. Ломоносова (1966-1979). 